\title{
Childhood Pleomorphic Rhabdomyosarcoma
}

National Cancer Institute

\section{Source}

National Cancer Institute. Childhood Pleomorphic Rhabdomyosarcoma. NCI Thesaurus.

Code C7959.

A rare aggressive rhabdomyosarcoma occurring in children. The neoplasm is

characterized by the presence of bizarre round, spindle, and polygonal cells. 